\title{
The Great GreeK AuCTION The Privatization of Utilities AND AsSets IN GREECE
}

\section{Daniel Haitas}

\begin{abstract}
With the onset of the Greek financial crisis in 2009 and the subsequent need for bailouts and loans from foreign creditors, Greece's publicly owned assets and state-run services were brought into focus and became the target for reform, restructuring and privatization. This received a new and drastic impetus last year as a result of the latest bailout agreement between Greece and its creditors, which requires that the country implement a wide-ranging privatization program to the value of 50 billion euros. Here we shall briefly overview the examples of water supply, electricity, and ports, all of which have been explicitly mentioned and singled out with regards to Greece's privatization push and attempts to reform state structures.
\end{abstract}

Keywords: Greece, financial crisis, public services, bailout, water supply, energy sector, privatization of ports, state-owned companies

\section{Introduction}

With the onset of the Greek financial crisis in 2009 and the subsequent need for bailouts and loans from foreign creditors, Greece's publicly owned assets and state-run services were brought into focus and became the target for reform, restructuring and privatization. This received a new and drastic impetus last year as a result of the latest bailout agreement between Greece and its creditors, which requires that the country implement a wide-ranging privatization program to the value of 50 billion euros (Kottasova, 2015). Here we shall briefly overview the examples of water supply, electricity, and ports, all of which have been explicitly mentioned and singled out with regards to Greece's privatization push and attempts to reform state structures.

\section{Privatization of Water Supply}

Greece has substantial water resources amounting to 58 billion cubic meters per year (Josephs, 2015). The country's two major suppliers of water, EYDAP in Athens and EYATH in Thessaloniki, are considered efficient overall in their operations (Kishimoto \& Hoedeman, 2015). As a result of 
Greece's economic crisis, the conservative government of Antonis Samaras (2012-2015) planned to privatize both EYDAP and EYATH, and interest was expressed in such a possibility by various foreign investors (Yallouros, 2014). However, this plan provoked considerable public opposition (Kishimoto \& Hoedeman, 2015). The Council of State, Greece's highest administrative court, in a 2014 decision stopped the privatization of a substantial amount of EYDAP, basing their ruling on the grounds that such an action might put public health at risk (Kishimoto \& Hoedeman, 2015). In that same year a non-binding referendum was also organised and held in Thessaloniki with 218, 002 participants, 98\% of which voted against the privatization of the city's water provider (Kishimoto \& Hoedeman, 2015).

\begin{tabular}{|c|c|c|c|}
\hline Privatisation Method & Advisors & Current Status & Next Steps - Main Issues \\
\hline $\begin{array}{l}\text { Sale of } 23 \% \text { of share } \\
\text { capital. } \\
\text { HRADF currently holds } \\
74 \% \text { of the shares. }\end{array}$ & & $\begin{array}{l}\text { Previous privatization attempt for the } \\
\text { sale of } 51 \% \text { was put on hold based on } \\
\text { the decision by the Council of State } \\
\text { regarding the similar privatisation of } \\
\text { EYDAP. According to the Court decision, } \\
\text { the state should retain at least } 50 \% \text { plus } \\
1 \text { share in EYDAP, so only a minority } \\
\text { stake can be sold. }\end{array}$ & $\begin{array}{l}\text { Next Steps } \\
\text { - HRADF to engage advisors } \\
\text { - Assessment of alternative options for the sale of } 23 \% \text { of the } \\
\text { - Impros } \\
\text { revised Concent of the regulatory framework and adoption of a }\end{array}$ \\
\hline
\end{tabular}

\begin{tabular}{|c|c|c|c|}
\hline \multicolumn{4}{|c|}{$\begin{array}{l}\text { 19. Athens Water Supply \& Sewerage S.A (EYDAP) } \\
\text { EYDAP has the exclusive right to offer water and sewerage services in the Greater Attica Area. The term of this right, as well as its renewal, is regulated by a a } 20 \text {-year } \\
\text { Agreement signed by the Hellenic Republic and EYDAP in } 1999 \text {. }\end{array}$} \\
\hline Privatisation Method & Advisors & Current Status & Next Steps - Main Issues \\
\hline $\begin{array}{l}\text { Sale of } 11 \% \text { of the shares. } \\
\text { HRADF holds } 27 \% \text { of the } \\
\text { shares. }\end{array}$ & & $\begin{array}{l}\text { According to decision by the Council } \\
\text { of State concerning the legality of } \\
\text { the transfer of the shares to the } \\
\text { HRADF, the transfer of } 34,0033 \% \text { of } \\
\text { EYADAP shares has been canceled. } \\
\text { Therefore, HRAADF owns } 27 \% \text { of } \\
\text { EYDAP shares and the HR } 34 \% \text {. } \\
\text { According to the Court decision, the } \\
\text { state should retain at least } 50 \% \text { plus } \\
1 \text { share, so only a minority stake can } \\
\text { be sold. }\end{array}$ & $\begin{array}{l}\text { Main Issuesto be addressed } \\
\text { 1. HR and HRADF to request return of capital to shareholders, as } \\
\text { provided in corporate law. } \\
\text { 2. HRADF to engage advisors. }\end{array}$ \\
\hline
\end{tabular}

Source: Asset Development Plan issued by the Hellenic Republic Asset Development Fund (July 30th, 2015)

There have been complaints of hypocrisy in relation to the push for Greece to privatize its water supply. George Archontopoulos, president of the Thessaloniki water company trade union, claimed that it is in fact a case of the Germans adopting a hypocritical „do as I say, but not as I do" approach to the issue (Mathiesen, 2015). The reason for this claim is the fact that in recent years there has actually been a move towards governments buying back water utilities in certain parts of Europe, such as in Germany and France (Mathiesen, 2015). Furthermore, there has been the criticism that overall the water supply system in Athens and Thessaloniki works fairly efficiently, thus calling into question the need to privatize (Mathiesen, 2015). In fact, it is said that the companies themselves are able to independently modernise their services and supply networks without the help of further private capital (Parliamentary questions to the Commission, 2013). Thus, it is claimed that the privatization has nothing to do with improving the provision of services, and everything to do with, in the words of one expert, „fiscal reasons" (Parliamentary questions to the Commission, 2013). However, despite such misgivings and opposition, under the terms of Greece's most recent bailout agreement with its creditors, Greece is to sell off large amounts of its water utilities in both Athens and Thessaloniki. According to the terms of the bailout, 11\% of EYDAP shares are to be sold off, which in reality means that $49.7 \%$ of the utility would be in private hands, as $38.7 \%$ of its shares are already in the ownership of private 
individuals and companies (Kishimoto \& Hoedeman, 2015). In relation to Thessaloniki's EYATH, 23\% of state-owned shares should be privatized, which means that on the whole $49 \%$ of the company's shares would be in private hands (Kishimoto \& Hoedeman, 2015). Though these figures mean that officially private investors would not have majority ownership over the companies, something explicitly prohibited by the 2014 Council of State's decision, in fact, at such high levels of privatization, some believe that they would effectively gain management control over the two companies (Kishimoto \& Hoedeman, 2015).

\section{Energy Sector Reforms}

A further condition of the latest bailout agreement is that Greece must make ,irreversible reforms" in the power and energy sectors, with a particular focus upon ADMIE, the country's electricity transmission company (Lewis, 2015). Greece's largest electric power company is the Public Power Corporation (DEI), which produces $80 \%$ of Greece's power output (Adamopoulos, 2015), 51\% of which is currently state-owned, with the remaining amount being held by private interests (Adamopoulos, 2015). Though officially ADMIE is owned by DEI, it acts as a separate company with its own independent operations and structures (Adamopoulos, 2015). The Samaras government had planned to carry out privatizations in this area, which attracted interest from such countries as Italy, China, Canada and Belgium (Tsagas, 2015). However, such measures were opposed by the government of Alexis Tsipras and so progress in this area came to a halt (Lewis, 2015).

A major criticism of the provision of energy services in Greece is its monopolistic nature and that it does not facilitate competition, but rather discourages it, and that in fact various Greek governments have actively supported the status quo (Tsagas, 2015). The desire to alter this state of affairs also can be related to the aim of creating a single EU energy market (Lewis, 2015) for purchases, supplies and consumption, and thus lower the cost of energy and diversify its supply (EU Commission, 2015).

According to the details of the latest bailout agreement, ADMIE should either be privatized or a solution should be found that would have an equivalent effect on competition (Makris, 2015). Despite this, the Greek government initially denied that there were plans to undertake a privatization campaign of ADMIE in the near future, and it sought alternative methods, which would have simultaneously avoided privatization while allowing for more competition in the energy sector (Adamopoulos, 2015). One such solution proposed by Minister Skourletis was for ADMIE to be removed from DEI's jurisdiction, without it being privatized (Adamopoulos, 2015). Eventually an agreement was reached with Greece's creditors, which entails the Greek state retaining 51\% ownership of ADMIE, with $20 \%$ to be bought by a strategic investor, while a further $29 \%$ will be floated on the Athens Stock Exchange (ADMIE, 2015). 


\section{Chinese Investment in the Greek Ports}

Another program originally planned by the Samaras government but subsequently put on hold due to the initial strong opposition of the Syriza government is the privatization of the Ports of Piraeus and Thessaloniki (Ekathimerini, 2015). Greece has the European Union's longest coastline and possesses the largest number of islands, and along with them a large number of ports (Corres \& Papachristou, 2013). The Port of Piraeus is the largest port hub in the country and accounts for $85 \%$ of Greece's passenger movements and cargo, while Thessaloniki is the second largest, and is geographically significant within Europe (Corres \& Papachristou, 2013). The Port of Piraeus was generally considered to have had an out dated infrastructure and to have been inefficient (Granitsas \& Paris, 2014), and the

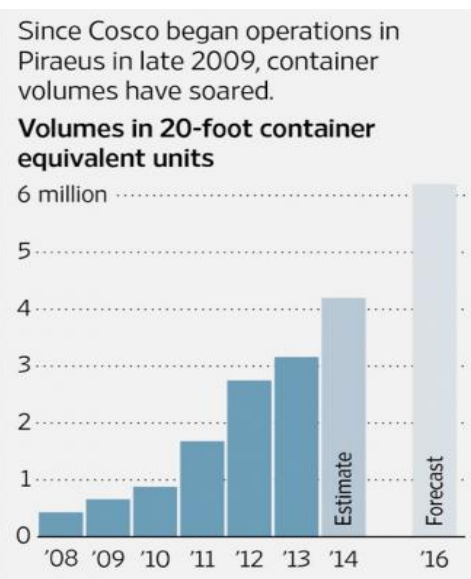
structure of its labour relations was considered cumbersome (Alderman, 2012). This changed, however, when the Chinese company COSCO became the operator of two of Piraeus' cargo piers in 2008, which led to an enormous boost in output and efficiency, and has generally been seen as a great success story (Smotlczyk, 2015), with the port becoming one of the fastest-growing and biggest in the Mediterranean (Granitsas \& Paris, 2014). COSCO expressed strong interest in gaining majority control over the entire port and was greatly concerned over Syriza's initial opposition to privatization (Smotlczyk, 2015). In the aftermath of the new bailout agreement, the Tsipras government began pressing ahead with the port privatization program, despite their initial opposition to it (Newton, 2015). The deadline for tenders for the privatization of the Port of Piraeus was set for the end of October last year and for the Port of Thessaloniki the deadline is the end of March 2016 (Reuters, 2015). With regards to Piraeus, it was China's Cosco Group that was successful in its bid, receiving approval from the Hellenic Republic Asset Development Fund to obtain a $67 \%$ share in the port (ShipTechnology, 2016).

\section{Conclusions}

National governments, ideally, should have the ability and will to organise the state and its structures according to the best interests of the country and its citizenry. This means that at various times the provision of certain services and assets should either remain in public hands or be privatized partially or completely, depending on what is most likely to lead to beneficial and successful results. In the case of Greece, in light of the developments over the last few years, it can be said that irresponsible administrative, economic and fiscal practices over recent decades have now led essentially to a loss of national sovereignty to a certain degree and of the ability of Greeks to decide in which way their country and its public administration should be ordered and structured. This is not to say that the 
movement towards privatization and restructuring in Greece is in itself a negative thing; on the contrary, in certain areas it has been necessary and vital. Indeed, with regards to ports we see that COSCO's operation in Piraeus has been overwhelming successful and beneficial. However, on the other hand, we can observe that in relation to the question of the privatization of water supply that the need now for the country to reach certain fiscal targets and fulfil its responsibilities to its creditors may lead to decisions and actions that may not necessarily be the most beneficial in terms of the ordering of the state and the provision of services to its citizens.

List of References:

Adamopoulos, A. (2015), Greek Energy Minister Asserts Greek Public Power Corporation Will Not Be Further Privatized. September 282015

ADMIE, (2015), Gov't, creditors agree on selloff fund, ADMIE, continue talks on NPLs. Ekathimerini. December 112015

Alderman, L. (2012). Under Chinese, a Greek Port Thrives. CNBC. October 102012

Corres, A. J. \& Papachristou, Y. (2013), Greek Ports: Market Transparency and Future Prospects. September 2013, p. 8

Ekathimerini (2015), Piraeus port U-turn will not hurt China investment: analysts. Ekathimerini. February 12015

EU Commission (2015), EU Commission approves proposals for single energy market. February 252015

Granitsas, A. \& Paris, C. (2014), Chinese Transform Greek Port, Winning Over Critics. The Wall Street Journal. November 202014

Greece announces deadline for port, railway privatization tenders. China Daily USA, August 132013

Josephs, J. (2015), Greece: Water Privatisation Battle. Water World

Kishimoto, S. \& Hoedeman, O. (2015), Leaked EU memorandum reveals renewed attempt at imposing water privatisation on Greece. TNI, August 242015

Kottasova, I. (2015), Bailout deal: What's for sale in Greece. CNN, July 142015

Lewis, B. (2015), Greece's creditors step up push for energy reforms. Reuters, June 262015

Makris, A. (2015), Greek Energy Minister Rules Out Privatization of Independent Power Transmission Operator. Greek Reporter, July 29 2015

Mathiesen, K. (2015), Germany's hypocrisy over Greece water privatization. The Guardian, August 142015

Newton, J. (2015), Greece sets deadline for port privatization. JOC.DOM. August 202015

Parliamentary questions to the Commission (2013), Privatisation of water supply services? EWA Newsletter, Issue 33, September 262013

Reuters (2015), Greek dock workers walk out over privatization. Reuters, October 222015

Ship-Technology (2016), Cosco's bid to acquire 67\% stake in Greek Port of Piraeus gets HRADF approval. Ship-Technology.com, February 192016 
Smotlczyk, A. (2015), One Port, Two Worlds: China Seeks Dominance in Athens Harbor. Der Spiegel. April 92015

Tsagas, I. (2015), What next for Greece's energy sector. PV Magazine, July 162015

Yallouros, L. (2014), Privatization of Greek water companies put off. Independent Balkan News Agency, July 152014 